\title{
THE USE OF CODE-MIXING BY ONLINE SELLERS ON FACEBOOK PAGE "PEKEN ONLINE BULELENG"
}

\author{
P.P. Novita Sari \\ English Language Education, Post Graduate Program, Universitas Pendidikan Ganesha, Singaraja \\ e-mail: pandeputunovitasari@gmail.com
}

This study investigated the phenomena of code-mixing in the language used in social media. This study aimed at describing (1) the kinds of code-mixing produced by online sellers; (2) the online sellers' response towards the use of code-mixing. The data collected through online sellers' comments, captions, status and, hashtags on Facebook. The data were analysed based on the linguistic form of code-mixing by Suwito's theory and the reasons for the use of code-mixing by Holmes Hoffman's theory. There were five steps in collecting the data, namely (1) opens the Facebook page; (2) screenshots code-mixing sentences; (3) writes code-mixing in the form of a table; (4) reads code-mixing sentences; (5) interviews the online sellers. The result showed that there were 50 code-mixing produced by online sellers. The online sellers frequently produced code-mixing in the form of words as a noun, phrase, adjective, clause, hybrid, repetition word and idiom. Meanwhile, the result of the interview showed that online sellers use code-mixing to get people's attention, limited words or unknown translation.

\section{Keywords: code-mixing, online sellers, Facebook page}

\section{INTRODUCTION}

Part of bilingualism consists of several terms, one of the terms is code-mixing. People sometimes mix or switch their language when they communicate with others both in bilingualism and multilingualism. Bilingualism means at first that the person can communicate in both languages and to apply the code-switching inadequate situations; this includes speaking and understanding as well as reading and writing. This is defined as the ability to articulate correctly, the use of adequate words in number and meaning and the knowledge of building correct words and phrases (Kokturk, Odaciaglu, \& Uysal, 2016) while multilingual (multilingualism) is a person who uses more than one language. In other words, when the speaker changes their language into mother tongue language (L1) or the situation where the people mix two languages when they speak or communicate with the other and it is called code-mixing. Code mixing is the use of two languages or more or two variants of a language in a speech community (Chair \& Leonie, 2004). Indonesia has many cultures, languages, dialects, and different geographic, thus that is a factor of the different language. Besides, culture is another factor that influences society, and social class also influencing different languages. The human capability is different; some people speak in two languages called bilingual. Moreover, many people who can speak more than two languages called multilingually. Every people have its ability; thus, they can speak more than one language (Riana, 2001).

Recently, the interest of learning and using foreign languages has increased. English is one of the foreign languages frequently used besides the mother tongue (Kurniawan, 2016).. With the growing influence of globalization, English is now considered as a lingua franca that is widely learned. Many Indonesian youngsters today use English in daily conversation and as a medium of communication besides their mother tongue. It can be observed that today these youngsters tend to code-switch and code-mix English and their local languages in their social communicative setting. This phenomenon can be seen when they use language in social media, the means of communication that is trending among youngsters nowadays, due to express their feeling, obtain information and find new friends. Facebook is one of the social networks that is growing rapidly than other social networks. It is one of the ten most popular social networking in the world used by youngsters aged $12-24$ years old. As of January 2011, the network was estimated to have more than 600 million monthly active users worldwide (Carlson, 2011). 
Facebook is a wide network that encourages many youngsters to be connected with more people, to be updated with the trends and news across the globe as well as to share their interests and voices to a wider audience. Facebook offers several features for its users to share and communicate their voices such as status is a feature to share a content on their profile, on their friends' walls and in Facebook news feeds, caption a short or even long explanation or description which includes an illustration, photo, location, emoticon, comment is a note explaining, illustrating, or criticizing the meaning of writing and hashtag is the users will be able to see all public content related to the keyword. These features allow users to explore and connect with their friends anytime and anywhere.

According to Kia et al. (2011), code-mixing is the change of one language to another in the same oral or written text. It is a common phenomenon in a society where two or more languages are used together. Studies of code-mixing let us know that when people producing language it is not only used one language but more than one language. In addition, it is described that code-mixing means the word (lexical) items and grammatical features of two languages that exist in the same sentence. Liu (2008) proposed three kinds of categories of code-mixing are as follows

1. Insertion: the sentences contain two languages such as mother tongue language and target language.

2. Alternation: the succession of fragments in mother tongue language and target language in a sentence, which is overall not identifiable as belonging to either A or B

3. Congruent lexicalization: the use of elements from either language in a structure that is wholly or partly shared by language mother tongue language and target language".

Furthermore, according to Kachru (1978), code-mixing refers to the use of the first language (mother tongue language) into another language (target language) for consistent transfer of linguistic units from one language into another language, and by few language mixtures developing a new restricted or not so restricted code of linguistic interaction." Furthermore, the use of code-mixing is not only wanted to make the meaning clear of the language but also there are several reasons for using code-mixing. Kurniawan (2016) identifies a few reasons for people to do code-mixing. These reasons are:

1. Talking about a particular topic means that people prefer to talk about a particular topic in any kind of subject that makes them comfortable to express their situation, particularly informal situations.

2. Quoting somebody else is restating the statement or saying famous expression written by the well-known figures.

3. Being emphatic about something is used in empathy and sympathy situation by mixing languages.

4. Inserting sentence fillers (interjection) in a certain situation of using language switching and language mixing, people tend to unintentionally or intentionally mark the interjection or sentence connector.

5. Expressing group identity (pride) in this kind of situation, there is a motive using the code-mixing to get people's attention and boost up their pride while communicating with others.

6. Limited Words or Unknown Translation, this kind of situation avoids misunderstanding and be more understandable by the interlocutor, people tend to mix the languages which have no translation in Indonesia.

Code mixing is usually occurring in the middle of a sentence. According to Kasyulita (2017) based on the unsure of language that involve in it, there are some forms of code mixing, they are:

a) Word insertion

b) Phrase insertion

c) Idiom or expression insertion

d) Hybrid insertion

e) Reduplication insertion.

There are also studies related to the use of code-mixing on social media especially 
Facebook was conducted by Kurniawan (2016) entitled Code-mixing on Facebook postings by EFL students: A small scale study at an SMP in Tangerang. In his study find out the code mixing's form use by EFL teenagers. This study found that English is frequently used by students in social media to perform code-mixing which are present in a caption, status, hashtag, and comments. As has been found in Kurniawan research (2016), reasons for code-mixing are identified as follows: 1) talking about a particular topic, 2) quoting somebody else's statements, 3) being emphatic about something, 4) interjection (inserting conjunction or sentence connectors), 5) gaining pride and 6) limited words.

Furthermore, the study of code-mixing also conducted by Kasyulita (2017) entitled Analysis of Students Code Mixing in Facebook Social Networking. This study, the researcher found that 160 in timeline and 35 in comment based on using code mixing form of words, phrases, hybrids, idioms, and reduplication. The conclusion of this research is students use two languages i.e. Indonesia and English as code-mixing.

Based on the theories stated previously and the studies. Code mixing mostly uses by language learners on social media. Therefore, this study aimed to investigate code mixing used by online sellers on Facebook Page "Peken Online Buleleng". The purpose of this study is to find out the kinds of code mixing's use by the online sellers and the reason for using code-mixing. The researcher uses the framework of Kasyulita (2017) to investigate the kind of code-mixing used by the online sellers and the theory (Kurniawan, 2016) to recognize the reason for using code-mixing.

\section{RESEARCH METHOD}

This study uses descriptive research in which describes code-mixing produced by the online sellers in the forms of status, comment, caption and hashtag on Facebook Page "Peken Online Buleleng". Descriptive research, as stated by Voordt, 2014), is describing how reality is not how it should be. Descriptive qualitative research is research without any statistic procedures in it. The aim is to describe what exists in reality concerning the variable of the condition (Syahrullah, 2015).

The subject of this study is code-mixing produced by online sellers on Facebook Page "Peken Online Buleleng". There were 50 code mixed sentences as a data source and were displayed in a table. The data was collected from November 8th, 2019 until December 10th, 2019. There were five steps to collect the data (1) the researcher open Facebook page of Peken Online Buleleng: (2) screenshots code-mixing sentences in the forms of status, comment, caption and hashtag (3) write code-mixing in the form of table; (4) reading the sentences made by online sellers to find out English words, (5) doing a quick survey through interviewed online sellers towards the response of using code-mixing

\section{FINDINGS AND DISCUSSION}

The result of the data is presented in the form of a table to make the data clear and well arranged in a pattern. Thus, it would be easier to read and understand. The data were collected from November 8th, 2019 until December 10th, 2019. The data took through screen shoots all online sellers' postings on Facebook page "Peken Online Buleleng", then it continued interviewed online sellers to find out their reason for using code-mixing in his/her statuses and comments. Below is the data in the form of a table that contains code-mixing includes Bahasa and English.

Table 1. Code-Mixing Produced by Online Sellers

\begin{tabular}{ll}
\hline No & \multicolumn{1}{c}{ Sentence } \\
\hline 1. & Mengerjakan service las panggilan dan finishing cat kayu dan besi \\
2. & Kualitas bahan sangat important, segera di order kakak \\
3. & Minat? Inbox aja keadaan hp masih bagus \\
4. & Yang mau HP murah, discount $60 \%$ \\
5. & Khusus untuk hari ini, kredit cukup bayar 99.000 tanpa survey \\
6. & Minat? Bisa comment dibawah ya \\
7. & Bisa langsung dikirim by JNE
\end{tabular}




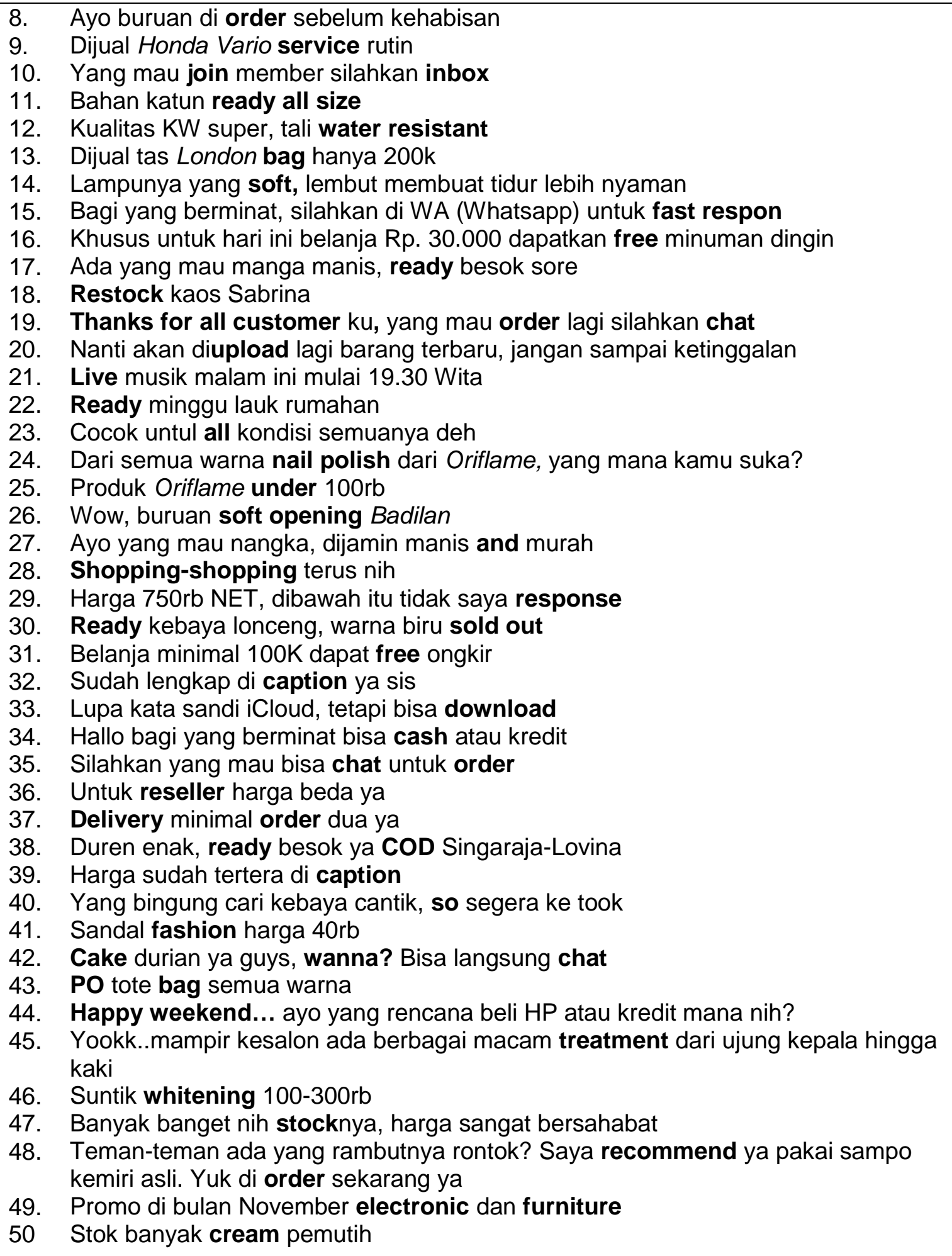

Based on the table above, it was found that fifty sentences produced by online sellers of "Peken Online Buleleng". It showed that online sellers frequently put the English word in the middle of the sentence.

There were fifty code-mixing sentences found on the Facebook page "Peken Online Buleleng" all the sentences were classified into five categories (Kasyulita, 2017) namely: Words, Phrases, Clauses, Hybrids, Repetition words, and Idioms. The classification of those categories is presented in the table below: 
Table 2. The Classification of Code-mixing

\begin{tabular}{|c|c|c|c|c|}
\hline No & & Types of Code Mixing & Words & In Bahasa \\
\hline \multirow[t]{37}{*}{1.} & Words & Noun & Cash & Tunai \\
\hline & & & Service & Pelayanan \\
\hline & & & Discount & Diskon \\
\hline & & & Comment & Komentar \\
\hline & & & Size & Ukuran \\
\hline & & & Cream & Krim \\
\hline & & & Nail polish & Cat kuku \\
\hline & & & Response & Jawaban \\
\hline & & & Caption & Judul \\
\hline & & & Download & Unduh \\
\hline & & & Delivery & Pengiriman \\
\hline & & & Fashion & Mode \\
\hline & & & Cake & Kue \\
\hline & & & Treatment & Perawatan \\
\hline & & & Furniture & Perabotan \\
\hline & & & Whitening & Memutihkan \\
\hline & & Adjective & Finishing & Menyelesaikan \\
\hline & & & Important & Penting \\
\hline & & & Ready & Siap \\
\hline & & & All & Semua \\
\hline & & & $\begin{array}{l}\text { Water- } \\
\text { resistant }\end{array}$ & Anti air \\
\hline & & & Soft & Lembut \\
\hline & & & Free & Gratis \\
\hline & & & Electronic & Elektronik \\
\hline & & Verb & Inbox & Pesan masuk \\
\hline & & & Survey & Memeriksa \\
\hline & & & Join & Bergabung \\
\hline & & & Restock & $\begin{array}{l}\text { Mengisi } \\
\text { kembali }\end{array}$ \\
\hline & & & Live & Hidup \\
\hline & & & Chat & Obrolan \\
\hline & & & Order & Memesan \\
\hline & & & Reseller & Dijual kembali \\
\hline & & & $\begin{array}{l}\text { Wanna (want } \\
\text { to) }\end{array}$ & Ingin \\
\hline & & & Recommend & Rekomendasi \\
\hline & & Preposition & By & Melalui \\
\hline & & & Under & Dibawah \\
\hline & & Conjunction & And & Dan \\
\hline
\end{tabular}




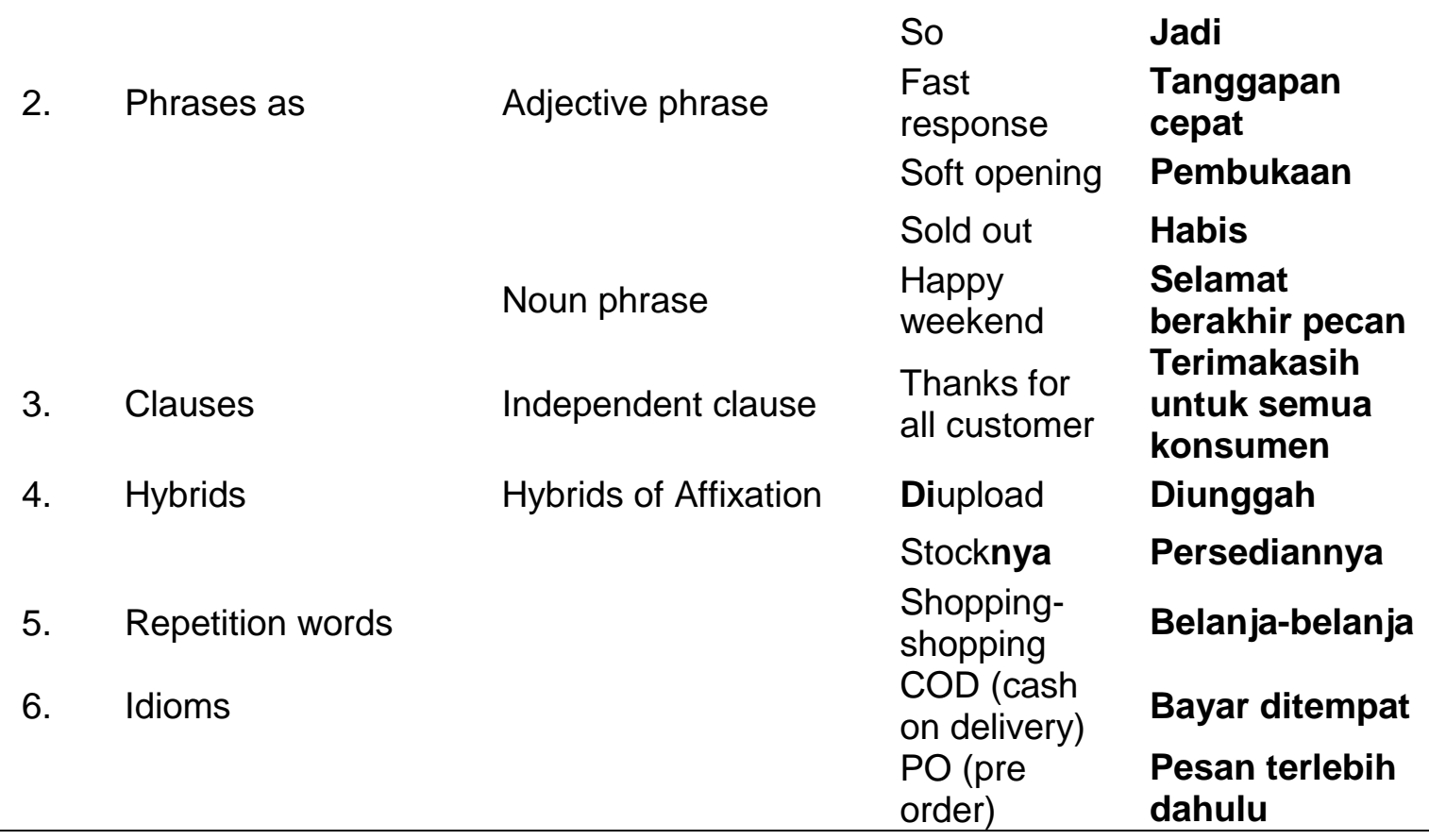

The table above showed that there were 6 categories of code-mixing namely words, phrases, clauses, hybrids, repetition words, and idioms. Those categories followed by their types. The first category is a word. Words are divided into five types namely words like noun, adjective, verb, preposition, and conjunction. The second is phrases as an adjective phrase. The third is a clause as an independent clause. The fourth is hybrids as hybrids of affixation. The fifth is repetition words and the last is idioms.

\section{Kinds of Code-mixing}

According to Yuliana, Luziana, and Sarwendah (2015), code-mixing is used interchangably with code-mixing which can be divided into three main types, namely (1) insertion (word or phrase); (2) alternation (clause); and (3) congruent lexical or can be called as dialect - and the most common occurrence of codemixing variants in society is insertional code-mixing.

There are three categories of code-mixing based on the grammatical structure (Yuliana et al., 2015):

1. Insertion: the sentences contain two languages such as mother tongue language and target language.

2. Alternation: the succession of fragments in mother tongue language and target language in a sentence, which is overall not identifiable as belonging to either A or B

3. Congruent lexicalization: the use of elements from either language in a structure that is wholly or partly shared by language mother tongue language and target language".

Furthermore, according to Kasyulita (2017), code-mixing divides into six categories there are words, phrases, clauses, hybrids, repetition words, and idioms. The definition is as follows:

\section{Words}

In Indonesia's utterances, there are some utterances that are inserting a foreign language. Sometimes, a foreign language is usually used in English. Sometimes, using English words in the Indonesia utterance is one or more English words, in this Code-Mixing classification called the insertion of words. The insertion of words arranged into eight groups, they are; noun, verb, adjective, adverb, conjunction, exclamation, and preposition (Riana, 2001). 


\section{a. Noun}

Noun is one of the most important parts of utterance, sentences, and speech. Its arrangement with the verb helps to form the sentence core which is essential to every complete sentence (Riana, 2001)]. In this research, the researcher found 13 English nouns inserted in the captions of online sellers. The English nouns inserted are tabulated as follows:

Table 3. The use of nouns in the captions of online sellers

\begin{tabular}{|c|c|c|}
\hline No & Sentences (Code-mixing) & English \\
\hline 1. & $\begin{array}{l}\text { Mengerjakan service las panggilan } \\
\text { dan finishing cat kayu dan besi }\end{array}$ & $\begin{array}{l}\text { Welding service and finishing iron } \\
\text { and wood paint. }\end{array}$ \\
\hline 4. & Yang mau HP murah, discount $60 \%$ & $\begin{array}{l}\text { Discount } 60 \% \text { of the cheap mobile } \\
\text { phone. }\end{array}$ \\
\hline 6. & Minat? Bisa comment dibawah ya & $\begin{array}{l}\text { Interested? Please comment } \\
\text { below. }\end{array}$ \\
\hline 11. & Bahan katun ready all size & Ready for all size of cotton stuff. \\
\hline 15. & $\begin{array}{l}\text { Bagi yang berminat, silahkan di WA } \\
\text { (Whatsapp) untuk fast response }\end{array}$ & $\begin{array}{l}\text { If you are interested, contact us } \\
\text { through Whatsapp. }\end{array}$ \\
\hline 24. & Dari semua warna nail polish dari & Since all variant's colours of \\
\hline & Oriflame, yang mana kamu suka? & Oriflame, which one do you like? \\
\hline 32. & Sudah lengkap di caption ya sis. & The caption is clear \\
\hline 33. & $\begin{array}{l}\text { Lupa kata sandi iCloud, tetapi bisa } \\
\text { download }\end{array}$ & $\begin{array}{l}\text { Forget iCloud password, but you } \\
\text { can still download }\end{array}$ \\
\hline 34. & $\begin{array}{l}\text { Hallo bagi yang berminat bisa cash } \\
\text { atau kredit }\end{array}$ & $\begin{array}{l}\text { If you interested, you can get it } \\
\text { through cash or credit. }\end{array}$ \\
\hline 37. & Delivery minimal order dua ya & Order minimum two to get delivery \\
\hline 42. & $\begin{array}{l}\text { Cake durian ya guys, wanna? Bisa } \\
\text { langsung chat }\end{array}$ & Call us, if you like Durian cake \\
\hline 45. & $\begin{array}{l}\text { Yookk.. mampir kesalon ada berbagai } \\
\text { macam treatment dari ujung kepala } \\
\text { hingga kaki }\end{array}$ & $\begin{array}{l}\text { Let's come for enjoying the } \\
\text { treatment of the body. }\end{array}$ \\
\hline 50. & Stok banyak cream pemutih & A lot of stocks of whitening cream \\
\hline
\end{tabular}

There are 13 words as nouns found in the sentences produced by online sellers on Facebook page "Peken Online Buleleng". The words were service, discount, comment, size, response, nail polish, caption, download, cash, delivery, cake, treatment, and cream.

\section{b. Adjective}

The adjective is a word used to explain noun or pronoun which can be a person, place, animal, object or abstract concept (thing). Regarding [9] adjectives can be defined at various of the organization of language, in particular, at the levels of morphosyntax, semantics, syntactic usage. In the morphosyntax perspective, languages frequently have no independent class of adjectives. Each lexicon can be combined with any type of grammatical items when it is used in a syntactic context by investigating the position from other constituents in the higher-order syntactic configurations. There were 8 English adjectives produced by online sellers on his/her postings on the Facebook page, as follows:

Table 4. The use of adjectives by online sellers

\begin{tabular}{lll}
\hline No & \multicolumn{1}{c}{ Sentences (Code-mixing) } & \multicolumn{1}{c}{ English } \\
\hline 1. & $\begin{array}{l}\text { Mengerjakan service las panggilan } \\
\text { dan finishing cat kayu dan besi }\end{array}$ & $\begin{array}{l}\text { Welding service and finishing iron and } \\
\text { wood paint. }\end{array}$ \\
2. & $\begin{array}{l}\text { Kualitas bahan sangat important, } \\
\text { segera di order kakak }\end{array}$ & $\begin{array}{l}\text { The quality of stuff is important, order } \\
\text { soon. }\end{array}$ \\
\hline
\end{tabular}




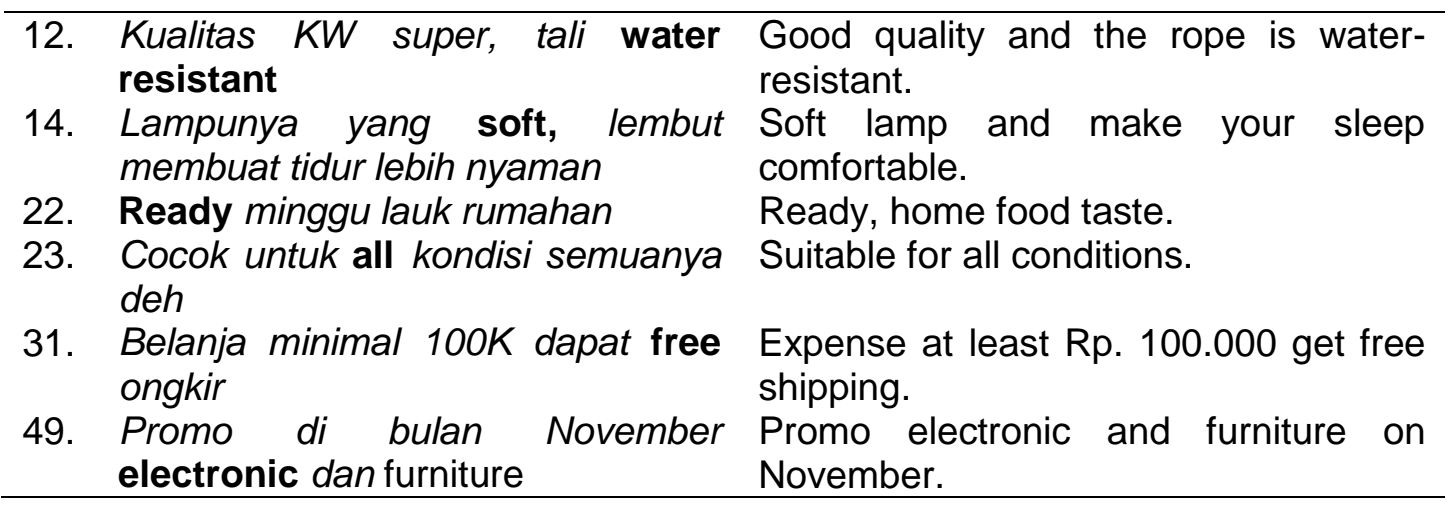

Based on the table above, it can be seen that there were 8 English adjectives produced by online sellers were service, important, water-resistant, soft, ready, all, free and electronic.

\section{c. Verb}

Verb is the word that showed some situation, attitude, action. Meanwhile, according to Harman (1978) verb is a word that functions to show the action of the subject, to indicate an event or situation. This is one of eight parts of speech.

There are 9 English verbs found in online sellers on Facebook Page "Peken Online Buleleng" are as follows:

Table 5. The use of verbs by online sellers

\begin{tabular}{|c|c|c|}
\hline No. & Sentences (Code-mixing) & English \\
\hline 5. & $\begin{array}{l}\text { Khusus untuk hari ini, kredit cukup } \\
\text { bayar } 99.000 \text { tanpa survey }\end{array}$ & $\begin{array}{l}\text { Special for today, only pay } \\
\text { Rp.99.000 without survey. }\end{array}$ \\
\hline 10. & $\begin{array}{l}\text { Yang mau join member silahkan } \\
\text { inbox }\end{array}$ & $\begin{array}{l}\text { If you want to join member, please } \\
\text { send a message. }\end{array}$ \\
\hline 18. & Restock kaos Sabrina & Restock Sabrina shirt \\
\hline 21. & $\begin{array}{l}\text { Live musik malam ini mulai } 19.30 \\
\text { Wita }\end{array}$ & $\begin{array}{l}\text { Live music tonight starts at } 19.30 \\
\text { Wita. }\end{array}$ \\
\hline 36. & Untuk reseller harga beda ya & Different prices for reseller \\
\hline 42. & $\begin{array}{l}\text { Cake durian ya guys, wanna? Bisa } \\
\text { langsung chat }\end{array}$ & If you like Durian cake, contact us. \\
\hline 48. & $\begin{array}{l}\text { Teman-teman ada yang rambutnya } \\
\text { rontok? Saya recommend ya } \\
\text { pakai sampo kemiri asli. Yuk di } \\
\text { order sekarang ya }\end{array}$ & $\begin{array}{l}\text { Is there anyone hair loss, I } \\
\text { recommend you to use original } \\
\text { Kemiri shampoo. Order now! }\end{array}$ \\
\hline
\end{tabular}

Based on the table above, there were 9 English verbs produced by online sellers were survey, join, restock, live, reseller, wanna (want to), chat, recommend and order.

\section{d. Preposition}

A preposition is a connecting word. In this sentence. The most commonly used prepositions include the following: in, with, to, from, at, of, by, for, under and on. The online sellers on Facebook Page "Peken Online Buleleng" use several English prepositions in his/her sentences, are as follows:

Table 6. The use of prepositions by online sellers

\begin{tabular}{lrl}
\hline No. & Sentences (Code-mixing) & \multicolumn{1}{c}{ English } \\
\hline 7. & Bisa langsung dikirim by JNE & Send through JNE \\
25. & Produk Oriflame under 100rb & $\begin{array}{l}\text { Oriflame product the price under } \\
\text { Rp. 100.000 }\end{array}$ \\
\hline
\end{tabular}


Based on the table above, it can be seen there were 2 prepositions found in the sentences were by and under.

\section{e. According}

According to Unubi (2019), conjunctions are the word for connecting the sentences. In these sentences, the online sellers used coordinate conjunction. Coordinate conjunction is simply referred to as coordinators, and the art of joining two words, phrases, clauses or sentences using coordinators is known as coordination. The function of the coordinate conjunction is to link the two sentences. For example, "Her daughter is a dentist and her son are studying law" There were two sentences used in English conjunction, are as follows:

Table 7. The use of conjunctions by online sellers

\begin{tabular}{lll}
\hline No. & Sentences (Code-mixing) & \multicolumn{1}{c}{ English } \\
\hline 27. Ayo yang mau nangka, dijamin & $\begin{array}{l}\text { Do you like jackfruit? It is sweet and } \\
\text { cheap. }\end{array}$ \\
40. $\begin{array}{l}\text { Yang and murah bingung cari kebaya } \\
\text { cantik, so segera ke toko }\end{array}$ & $\begin{array}{l}\text { Are you confuse to find Kebaya? } \\
\text { Let's come to the shop. }\end{array}$ \\
\hline
\end{tabular}

Based on the table above, it can be seen that there were two conjunctions found in the sentences were and and so.

\section{Phrase}

There were two kinds of phrases found on Facebook Page "Peken Online Buleleng" were adjective phrases and noun phrases. According to Dirseciu (2017), noun phrase can be seen as a headed phrase in which the head is the only obligatory constituent. The construction of an NP is always recursive since several dependents can be added to the head element to make two common structures: simple vs. complex noun phrases. there were two phrases such as adjective phrase and a noun phrase, are as follows:

\section{a. Adjective phrase}

According to Sulistyowati (2015) stated that adjectives phrase is a phrase which has an adjective as a head element like extremely happy, quite large, etc. Semantically, there are two types of adjectives are standard and non-standard adjectives. The standard adjective defines as a quality meanwhile the non-standard adjective is limited in use. There were two sentences used adjective phrase in code-mixing sentences, are as follows:

Table 8. The use of adjective phrases

\begin{tabular}{lll}
\hline No. & \multicolumn{1}{c}{ Sentences (Code-mixing) } & \multicolumn{1}{c}{ English } \\
\hline 15. & $\begin{array}{l}\text { Bagi yang berminat, silahkan di } \\
\text { WA (Whatsapp) untuk fast through Whatsapp. } \\
\text { respon }\end{array}$ & $\begin{array}{l}\text { For past response please contact } \\
\text { Wow, buruan soft opening Soft opening Badilan. Come soon! } \\
\text { Badilan }\end{array}$ \\
$\begin{array}{l}\text { Ready kebaya lonceng, warna } \\
\text { biru sold out }\end{array}$ & $\begin{array}{l}\text { Ready Kebaya Lonceng, for blue } \\
\text { colour sold out. }\end{array}$ \\
\hline
\end{tabular}

Based on the table above, it can be seen that there were three adjective phrases on online sellers' comment, status, hashtag and caption were fast response, soft opening and sold out.

\section{b. Noun Phrase}

A noun phrase is a grammatical class consisting of a noun or pronoun and any 
immediate modifiers (the term modifier refers to any grammatical element which limits the meaning of some other element (Sulistyowati, 2015). Meanwhile, noun phrases also can be defined as a group of words with a noun or pronoun as the main part. There was one sentence used noun phrase is follow:

Table 9. The use of Noun phrases by online sellers

\begin{tabular}{|l|l|l|}
\hline No. & \multicolumn{1}{|c|}{ Sentence } & \multicolumn{1}{|c|}{ English } \\
\hline 44. & $\begin{array}{l}\text { Happy weekend... ayo yang } \\
\text { rencana beli HP atau kredit } \\
\text { mana nih? }\end{array}$ & $\begin{array}{l}\text { Happy weekend... Come on, for you } \\
\text { want to buy mobile through cash or } \\
\text { credit? }\end{array}$ \\
\hline
\end{tabular}

Based on the table above it can be seen that there was one phrase as noun phrase was happy weekend.

\section{Clause}

A clause is a group word that contains subject and predicate (Dickerson, n.d.). Clauses divide into two types they are independent clause and a dependent clause.

Table 10. The use of clauses by online sellers

\begin{tabular}{lll}
\hline No & \multicolumn{1}{c}{ Sentence } & English \\
\hline 19. & Thanks for all customer ku, \\
yang mau order lagi silahkan \\
chat.
\end{tabular}

Based on the table above, it can be seen that, there was one clause in the sentence.

\section{Hybrids}

Hybrid is a word or phrase that one part derived from one language and another part derived from a different language. Hornby states that Hybrid is composed of parts of words. Hybrid can be classified into two types. They are hybrid of affixation and hybrid of phrase. In this study, there was found the only hybrid of affixation.

a. Hybrid affixation

Affixation is a process that contains adding bound morphemes to roots which results in a new form. In English pre-fixation, the word can call pre-fixation when adding morpheme before the root, examples of pre-fixation: pre-, up-, in-, un-, re-, etc. Then, the word can be called suffixation when adding morpheme after the root, examples of suffixation: -ly, -ed, -er, -ion, etc (Riana, 2001).

Table 11. The use of Hybrids by online sellers

\begin{tabular}{lll}
\hline No. & \multicolumn{1}{c}{ Sentences } & \multicolumn{1}{c}{ English } \\
\hline 20. & $\begin{array}{l}\text { Nanti akan diupload lagi barang } \\
\text { terbaru, jater the latest items will be } \\
\text { ketinggalan } \\
\begin{array}{l}\text { Banyak banget nih stocknya, } \\
\text { harga sangat bersahabat }\end{array}\end{array}$ & $\begin{array}{l}\text { There are so many stocks, the price } \\
\text { is very cheap. }\end{array}$ \\
\hline
\end{tabular}

There were two hybrid affixations produced by online sellers, they were diupload and stocknya.

\section{Repetition Word}

This study found that online sellers use repetition words in English. The repetition word of shopping-shopping is based on Indonesian structure, meanwhile in English, if the word is plural should add by -s. 
Table 12. The use of repetitive words

\begin{tabular}{lcc}
\hline No. & Sentence & English \\
\hline 28. & Shopping-shopping terus nih & always shopping. \\
\hline
\end{tabular}

There was one repetition word produced by online sellers was shopping-shopping.

\section{Idioms}

An idiom is a group of words that has a meaning that is distinguished from the meaning of all the individual (Adger, 2003). In other words, language expressions in the form of a combination of words (phrases) whose meanings are integrated and cannot be interpreted with the meanings of the elements that form them.

Table 13. The use of Idioms

\begin{tabular}{lll}
\hline No. & \multicolumn{1}{c}{ Sentences } & \multicolumn{1}{c}{ English } \\
\hline 38. & $\begin{array}{l}\text { Duren enak, ready besok ya } \\
\text { COD Singaraja-Lovina }\end{array}$ & $\begin{array}{l}\text { Tasty Durian, tomorrow is ready for } \\
\text { cast on delivery around Singaraja- } \\
\text { Lovina. }\end{array}$ \\
43. PO tote bag semua warna & Pre order tote bag for all colours. \\
\hline
\end{tabular}

The table above showed that there were two idioms produced by online sellers in the The table above showed that there were two idioms produced by online sellers in the sentences.

The result of this study was the same as with the previous research conducted by Kasyulita (2017)] entitled Analysis of Students Code Mixing in Facebook Social Networking which was found that 160 in timelines and 35 in comment based on using code mixing form of words, phrases, hybrids, idioms, and reduplication. However, this study also found that the online sellers frequently use English words such as word as noun, adjective, verb, preposition, and conjunction and there were also used phrases, hybrids, idioms and repetition words.

\section{Reason for Code-mixing}

The researcher interviewed online sellers to find out their reasons for using code-mixing in his/her statuses or comments on Facebook page. Thus, this study found that the reason the use of code-mixing by online sellers was to gain customers' attention to buy the product. This reason is related with Kurniawan, B. (2016) stated that (1) using the code-mixing to get people's attention and boost up their pride while communicating with others; (2) limited Words or Unknown Translation, this kind of situation avoid them misunderstanding and be more understandable by the interlocutor, people tend to mix the languages which has no translation in Indonesia; (3) Quoting somebody else is restating the statement or saying famous expression written by the well-known figures. Those reasons were stated by online sellers. Thus, it can be concluded that code-mixing just not only used for their pride but also to make the customers understand familiar terms such as COD (cash on delivery), Ready (the product is available), etc.

\section{CONCLUSION AND SUGGESTIONS}

Phenomena of code-mixing are familiar in Indonesia. People sometimes mix or switch their language when they communicate with others both in oral and written. Facebook is media social use by most of the people around the world. Recently many sellers sell their products or items through Facebook. Most online sellers use English forms in their caption, comment, status, and hashtag. This study investigated code-mixing produced by online sellers on the Facebook page "Peken Online Buleleng". The result of the study showed that there were 50 code-mixing, the online sellers frequently produced code-mixing in the form of words as a noun, phrase, adjective, clause, hybrid, repetition word and idiom. Meanwhile, the result of the interview showed that online sellers use code-mixing to get people's attention, limited words or unknown translation. 
The benefit of this research is researcher gets information on why the online sellers use code-mixing. Meanwhile, for future study, the other researcher can conduct the research related to code-mixing in the different subject fields, for example in the classroom context in which code-mixing produced by EFL students and its effects of language acquisition.

\section{REFERENCES}

Adger, D. 2003. Core syntax. Oxford, UK: Oxford University Press.

Chaer, abdul \& Leonie Agustina. 2004. Sosiolinguistik: Perkenalan Awal. Jakarta: PT Rineka Cipta

Carlson, N. (2011, January 5). Facebook has more than 600 million users, Goldman tellsclients. The Business Insider. Retrieved from http://www.businessinsider.com/facebook-has-more-than-600-millionusersgoldmantells-clients-2011-1.

Dickerson.M. (n.d.). An Introduction to Clauses. 1-17.

DIRSECIU, P. (2017). Noun Phrase Construction in Academic Research Articles. III(Vi), 114.

Harman, G. (1978). Meaning and Theory. In Southwestern Journal of Philosophy (Vol. 9). https://doi.org/10.5840/swjphil19789222

Henk van Riemsdjik \& Istvan Kenesei, series editors. (2003). Syntax of. 3, 1-63. https://doi.org/10.1016/j.bcmd.2006.11.004

Heny sulistyowati. (2015). Function of Adjective Phrase - Indonesian English. IOSR Journal Of Humanities And Social Science Ver. IV, 20(10), 45-51. https://doi.org/10.9790/0837201044551

Jitpranee, J. (2017). A Study of Adjective Types and Functions in Popular Science Articles. International Journal of Linguistics, 9(2), 57. https://doi.org/10.5296/ijl.v9i2.10811

Kasyulita, E. (2017). Analysis of Students Code Mixing in Facebook.

Kia, L. S., Cheng, X., Yee, T. K., \& Ling, C. W. (2011). Code-Mixing of English in the Entertainment News of Chinese Newspapers in Malaysia. International Journal of English Linguistics, 1(1), 3-14. https://doi.org/10.5539/ijel.v1n1p3

KÖKTÜRK, Ş., Odacıoğlu, M. C., \& UYSAL, N. M. (2016). Bilingualism and Bilingual Education, Bilingualism and Translational Action. International Journal of Linguistics, 8(3), 72. https://doi.org/10.5296/ijl.v8i3.9601

Kurniawan, B. (2016). Code-mixing on Facebook Postings by EFL Students: a Small Scale Study at an SMP in Tangerang. Indonesian JELT, 11(2), 169-180. https://doi.org/10.25170/ijelt.v11i2.828

Kachru, B. B. (1978). Toward Structuring Code-Mixing: An Indian Perspective. International Journal of the Sociology of Language, 16, 27-46

Liu, P. (2008). Code-switching and Code-mixing. GRIN Verlag.

Prepositions, U. (1987). GRAMMAR AND MECHANICS Using Prepositions.

Riana, R. D. (2001). A corpus-based sociolinguistic study on the use of. 1-13.

Syahrullah, A. S. (2015). RESEARCH PAPER PERMEABILITY OF INTERLANGUAGE SYSTEM: A CASE STUDY OF INTERLANGUAGE SYSTEM OF JUNIOR HIGH SCHOOL STUDENTS OF SMP N 2 SURAKARTA LEARNING ENGLISH AS A FOREIGN LANGUAGE.

Unubi, A. S. (2019). Conjunctions in English: Meaning, Types and Uses. International Journal of Social Science and Humanities Research, 4(3).

Voordt, T. j M. Van der. (2014). Ways to study - Descriptive research. Research Gate, (September 2002). 
JPBII, Vol. 8 No. 1 (2020)

ISSN: 2541-7207

Yuliana, N., Luziana, A. R., \& Sarwendah, P. (2015). Code-Mixing and Code-Switching of Indonesian Celebrities: A Comparative Study. Lingua Cultura, 9(1), 47. https://doi.org/10.21512/lc.v9i1.761 